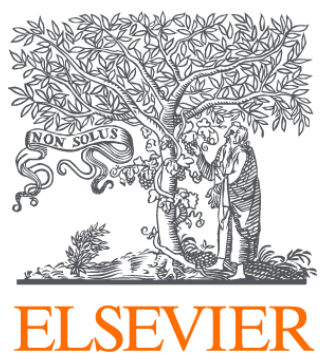

Since January 2020 Elsevier has created a COVID-19 resource centre with free information in English and Mandarin on the novel coronavirus COVID-

19. The COVID-19 resource centre is hosted on Elsevier Connect, the company's public news and information website.

Elsevier hereby grants permission to make all its COVID-19-related research that is available on the COVID-19 resource centre - including this research content - immediately available in PubMed Central and other publicly funded repositories, such as the WHO COVID database with rights for unrestricted research re-use and analyses in any form or by any means with acknowledgement of the original source. These permissions are granted for free by Elsevier for as long as the COVID-19 resource centre remains active. 


\title{
Mouse Hepatitis Virus Type 3 Infection Provokes a Decrease in the Number of Sinusoidal Endothelial Cell Fenestrae Both In Vivo and In Vitro
}

\author{
Anne-Marie Steffan, ${ }^{1}$ Carlos Augusto Pereira, ${ }^{2}$ Annick Bingen, ${ }^{1}$ Michele Valle, ${ }^{1}$ \\ Jean-Pierre Martin, ${ }^{1}$ Françoise Koehren, ${ }^{1}$ Cathy Royer, ${ }^{1}$ Jean-Louis Gendrault, ${ }^{1}$ and André Kirn $^{1}$
}

\begin{abstract}
Fenestrations of hepatic endothelial cells play an active role as a sieving barrier allowing extensive exchange between the blood and liver parenchyma. Alteration of these structures may be induced in the course of various pathological events and provoke important perturbations of liver function. We demonstrate here that sinusoidal endothelial cells are permissive for mouse hepatitis virus 3 (MHV3) in vivo and in vitro and that this infection leads to a striking decrease in the number of fenestrae. The disappearance of these structures observed under scanning electron microscopy or in cryofracture preparations in vivo and in vitro cannot be reversed by the action of cytochalasin $B$ on the microfilament network. The decrease in the porosity seems to be related directly to the productive infection of the endothelial cells, because it was not observed in $\mathrm{A} / \mathrm{J}$ mice resistant to the virus and in susceptible $B A L B / c$ mice immunized with a thermosensitive mutant in which no viral replication occurs. In conclusion, a viral infection of liver endothelial cells may cause extensive loss of the fenestrations and thus lead to important functional pertubations. (HePATOLOGY 1995;22:395-401.)
\end{abstract}

The role of the endothelial cells (EC) of the hepatic sinusoid as a sieving barrier between the sinusoid and the space of Disse has been evoked by several authors. ${ }^{1-11}$ We demonstrated that the damage to the sinusoidal lining allows viruses that are normally nonhepatotropic to infect hepatocytes. ${ }^{12,13}$ Although the experimental evidence is still limited, there are some arguments to support the view that EC may control the entry of chylomicrons into the space of Disse ${ }^{1-3}$ and thus play a role in the lipoprotein metabolism of the liver. ${ }^{6-8}$ Moreover, it appears that the filtering capacity

Abbreviations: EC, endothelial cells; CB, cytochalasin B; MHV3, mouse hepatitis virus 3 .

From the ${ }^{1}$ Unité INSERM 74 et Institut de Virologie de la Faculté de Médecine, Strasbourg, France; and ${ }^{2}$ Instituto Butantan, Imunology Viral, SaoPaolo, Brazil.

Received November 2, 1994; accepted March 7, 1995.

Address reprint requests to: Anne-Marie Steffan, PhD, Unité INSERM 74 et Institut de Virologie de la Faculté de Médecine, 3 rue Koeberlé, 67000 Strasbourg, France.

Copyright $\odot 1995$ by the American Association for the Study of Liver Diseases.

0270-9139/95/2202-0003\$3.00/0 of EC may change according to the animal species ${ }^{14}$ and may be modified under the influence of various factors. ${ }^{2,5,7,8,15-34}$ We have shown that cytochalasin B (CB), which alters the microfilaments, produces a considerable increase in the porosity of EC. ${ }^{35}$

Because several viruses provoke an alteration of the cellular cytoskeleton ${ }^{36-41}$ and because cultured liver EC may be infected by viruses,${ }^{42-44}$ we found it interesting to study the effect of the infection of EC on the fenestration pattern. This question is of particular importance, because (1) defenestration of hepatic sinusoids has been evoked as a cause of hyperlipoproteinemia ${ }^{14} ;(2)$ several authors have speculated about an eventual role of viruses in atherogenesis. ${ }^{8}$

In this study we demonstrate that mouse hepatitis virus 3 (MHV3), which infects EC, ${ }^{43,44}$ produces a considerable reduction in the number of their fenestrae, thus leading to a drastic diminution in the porosity of the cells.

\section{MATERIALS AND METHODS}

Mice. $\mathrm{A} / \mathrm{J}$ and $\mathrm{BALB} / \mathrm{c}$ mice (20 to $25 \mathrm{~g}$ body weight) were obtained from the Centre de Sélection et d'Elevage d'Animaux de Laboratoire (Orléans, France) and IFFA CREDO (L'Arbresle, France), respectively, and kept under conventional conditions. Care of animals followed the appropriate guidelines. Six- to 8-week-old animals were infected intraperitoneally with $2 \times 10^{3}$ pfu (plaque-forming units) of MHV3 for 24 ( 5 animals) and 48 (5 animals) hours.

Immunization. A nonpathogen temperature-sensitive mutant of MHV3, D222 ${ }^{45}$ was injected three times intraperitoneally at 2 -week intervals into BALB/c mice $\left(10^{3} \mathrm{pfu} /\right.$ injection $)$.

Chemicals. Collagenase CLS from Clostridium histolyticum was purchased from Worthington (Millipore Corp., Bedford, MA). CB, obtained from Sigma Chemical Co. (St Louis, MO), was dissolved with dimethylsulfoxide $(2.5 \mathrm{mg} / \mathrm{mL})$ and then diluted with Dulbecco's modified Eagle medium to obtain a final concentration of $10 \mu \mathrm{g} / \mathrm{mL}$.

Liver Perfusion In Situ. Mice were anesthetized with ether and their livers perfused in situ through the portal vein with oxygenated Dulbecco's modified Eagle medium with or without $10 \mu \mathrm{g} / \mathrm{mL} \mathrm{CB}$, at a flow rate of $2 \mathrm{~mL} / \mathrm{min}$ for 1 hour at $37^{\circ} \mathrm{C}$. The livers were then fixed by perfusion for electron microscopy.

Isolation of Liver EC. EC from the liver were obtained by collagenase perfusion and centrifugal elutriation as described before. ${ }^{46.47}$ 
Morphological Examinations. The cells were fixed with $2.5 \%$ glutaraldehyde in $0.075 \mathrm{~mol} / \mathrm{L}$ cacodylate buffer, $\mathrm{pH}$ 7.4 , containing $4.5 \%$ sucrose, $1 \mathrm{mmol} / \mathrm{L} \mathrm{MgCl}_{2}$ and $1 \mathrm{mmol} / \mathrm{L}$ $\mathrm{CaCl}_{2}$. The livers were fixed by perfusion through the portal vein with the same fixative. For transmission electron microscopy, the cells and small liver blocks were postfixed with $1 \%$ phosphate-buffered $\mathrm{OsO}_{4}$, dehydrated with ethanol, and embedded in Lx 112 (Ladd, Burlington, VT). For scanning electron microscopy, the cells and the liver samples were dehydrated with ethanol, dried with hexamethyldisilazane, ${ }^{48}$ and coated with gold.

For freeze-fracture, small blocks of livers were immersed in $30 \%$ glycerol in cacodylate buffer for at least 1 hour at $4^{\circ} \mathrm{C}$ then cut to fit in the specimen holder and frozen in subcooled nitrogen. Freeze-fracture replicas obtained in a ReichertJung 190 Cryofract freeze-fracture device (Cambridge Instruments, Villepinte, France) were cleaned with sodium hypochloride, washed in three changes of distilled water, and mounted on hexagonal 700-mesh gold grids. The samples were observed either in a Philips EM 410 or in a Philips SEM $501 \mathrm{~B}$ (Eindhoven, The Netherlands) electron microscope, respectively.

Morphometry. The measurements of the different parameters were performed on scanning electron microscopy photographs with a Kontron semiautomatic MOP videoplan analyzer (Eching-Munich, Germany). To determine the diameter and the porosity (which is the percentage of the cell surface opened by fenestrae), approximately $1,000 \mu \mathrm{m}^{2}$ was measured at a magnification of $\times 20,000$.

\section{RESULTS}

Infection of BALB/c Mice. Twenty-four hours after infection, most of the liver tissue of $\mathrm{BALB} / \mathrm{c}$ mice is well preserved: there are no necrotic foci, no obvious cellular alterations, and a few Kupffer cells and EC appear to be infected by the virus under electron microscopy (results not shown). However, as compared with EC from a control mouse, which exhibit typical sieve plates (Fig. 1A), all the EC of infected mice appear rather devoid of pores in the whole liver after 48 hours (Fig. 1B). This reduction in the number of fenestrae was restricted to the periportal area 24 hours after infection. MHV3 particles on the way to, or that have already been released by, the cell could also be observed (Fig. 1C). The cellular surface displays an irregular aspect because of the presence of numerous small bulging craters (Fig. 1C), which may represent the stage preceding the disappearance of the fenestrae.

Morphometric examinations have demonstrated a drop in the porosity of the endothelial lining from 10.0 $\pm 3 \%$ in controls, to $1.0 \pm 0.2 \%$ in 48 -hour-infected mice, the diameter of the fenestrae being $100 \pm 16$ $\mathrm{nm}$ and $73 \pm 13 \mathrm{~nm}$, respectively. The decrease in the porosity of the endothelial lining was also observed in cryofracture preparations. In control animals, clusters of rounded structures containing ice and therefore representing fenestrae were disseminated all over the surface of the sinusoid (Fig. 2A). In contrast, the surface of sinusoids of infected mice displayed a reduced number of fenestrae (Fig. 2B). It must be noticed that besides this lack of pores, the membrane of the EC seemed normal, as far as the number and appearance of the intramembrane particles are concerned.
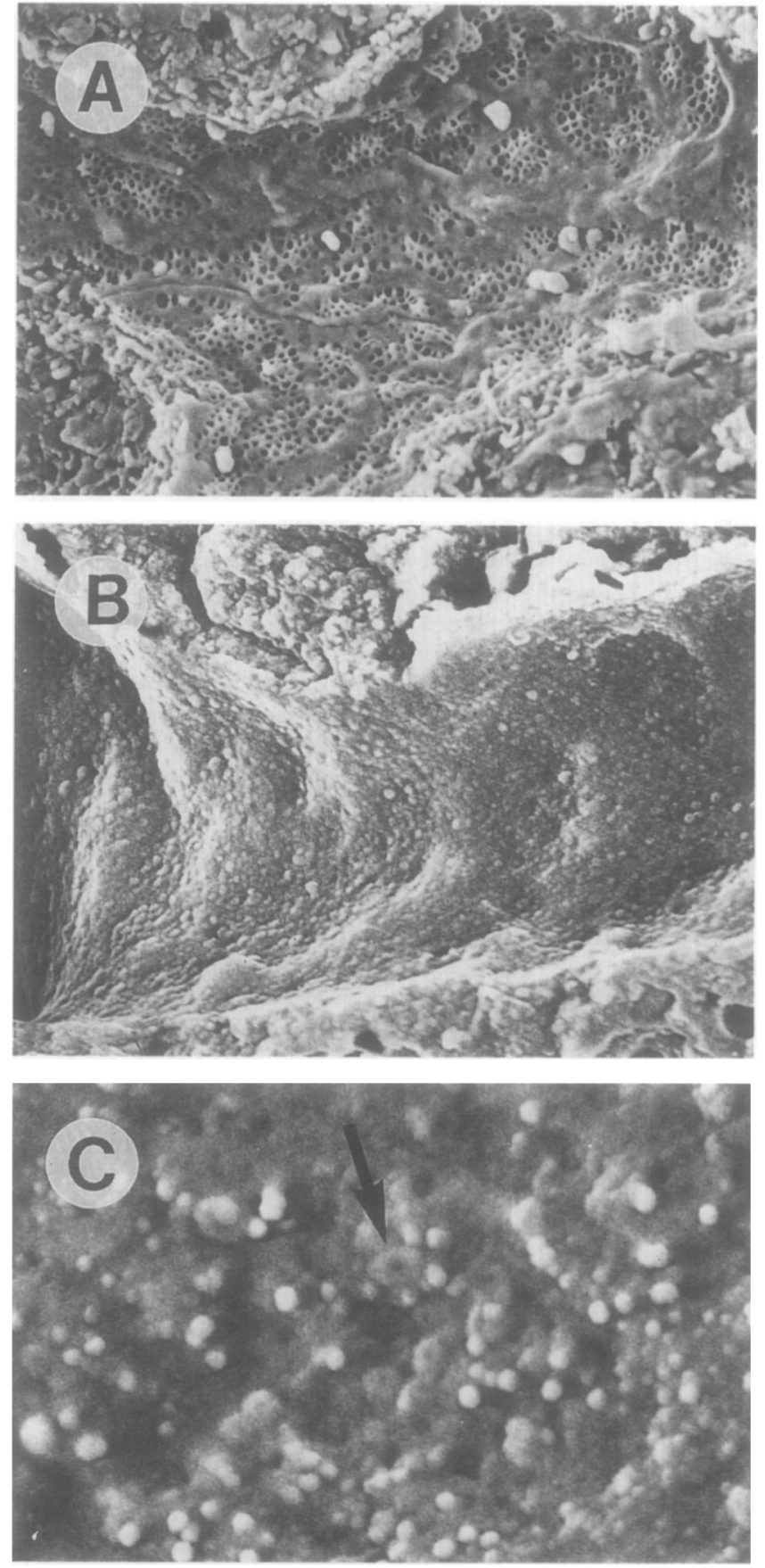

FIG. 1. Effect of MHV3 infection on the fenestration pattern of susceptible BALB/c mouse liver EC. Sinusoid in a control animal, displaying well-preserved fenestrae (A). (Original magnification $\times 7,000$.) Sinusoid of a mouse infected for 48 hours appearing devoid of pores $(\mathrm{B})$. (Original magnification $\times 7,000$.) A high magnification suggests the budding of MHV3 particles at the cellular membrane. The surface of the cell is rough owing to the presence of small bulging craters (arrow) (C). (Original magnification $\times 30,000$.)

The reduction in the number of pores was also confirmed by the observation of thin sections from 48-hourinfected mice livers. At the same time, numerous virus particles have been produced and may be found either in the EC (Fig. 3A) or in the space of Disse on the 

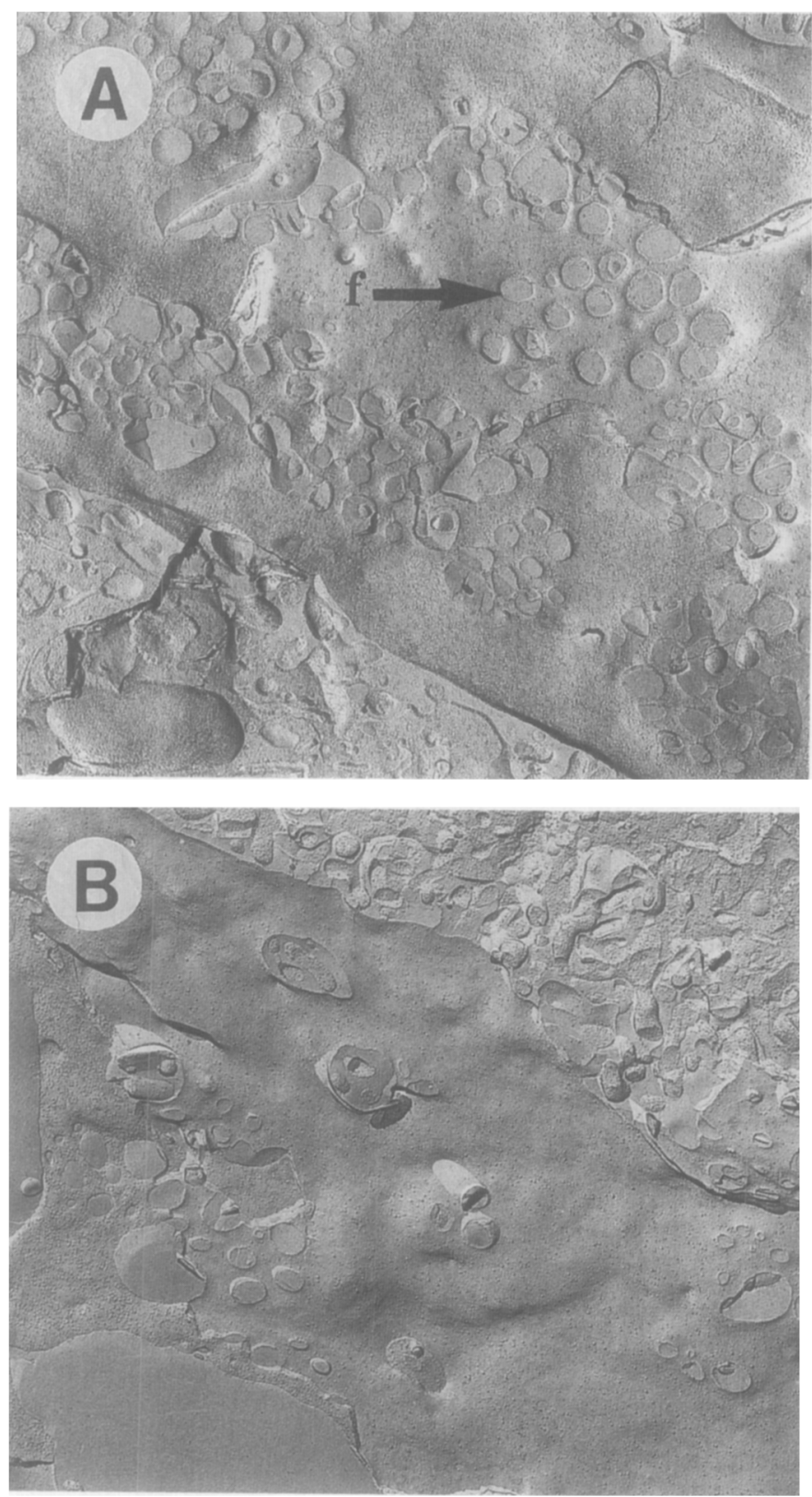

FIG. 2. Cryofracture study of the sinusoids of infected or noninfected BALB/c mice. In the control numerous fenestrae (f) are present (A). (Original magnification $\times 25,000$.) In the animals infected for 48 hours, their number is notably reduced and the regular distribution of intramembrane particles suggests that fenestrae were not only shrunken, but completely disappeared (B). (Original magnification $\times 25,000$.

way to infect the hepatocytes (Fig. 3B). MHV3 antigens shown by immunofluorescence were frequently associated with the endothelial lining at that time of infection (results not shown).

Infection of Immunized BALB/c Mice and Genetically Resistant A/J Mice. To know if the alteration of the fenestration pattern is related to virus multiplication, experiments were carried out in immunized susceptible $\mathrm{BALB} / \mathrm{c}$ mice and in $\mathrm{A} / \mathrm{J}$ mice genetically resistant to
MHV3, in which the replication of the virus is restricted. BALB/c mice were immunized with a thermosensitive mutant of MHV3 conferring protection against a lethal challenge with the wild strain. When immunized animals were infected with MHV3, neither viral antigens nor necrotic foci could be detected. Examination under scanning electron microscopy of liver specimens of animals infected for 48 hours showed well-preserved fenestrae (Fig. 4A) with a porosity similar to controls of around $10 \%$.

In $\mathrm{A} / \mathrm{J}$ mice, viral replication in the liver is restricted. Forty-eight hours after infection, only a few inflammatory foci may be found. At the same time, the fenestration pattern of the EC appears similar to that of uninfected animals (Fig. 4B), with a porosity of approximately $10 \%$.
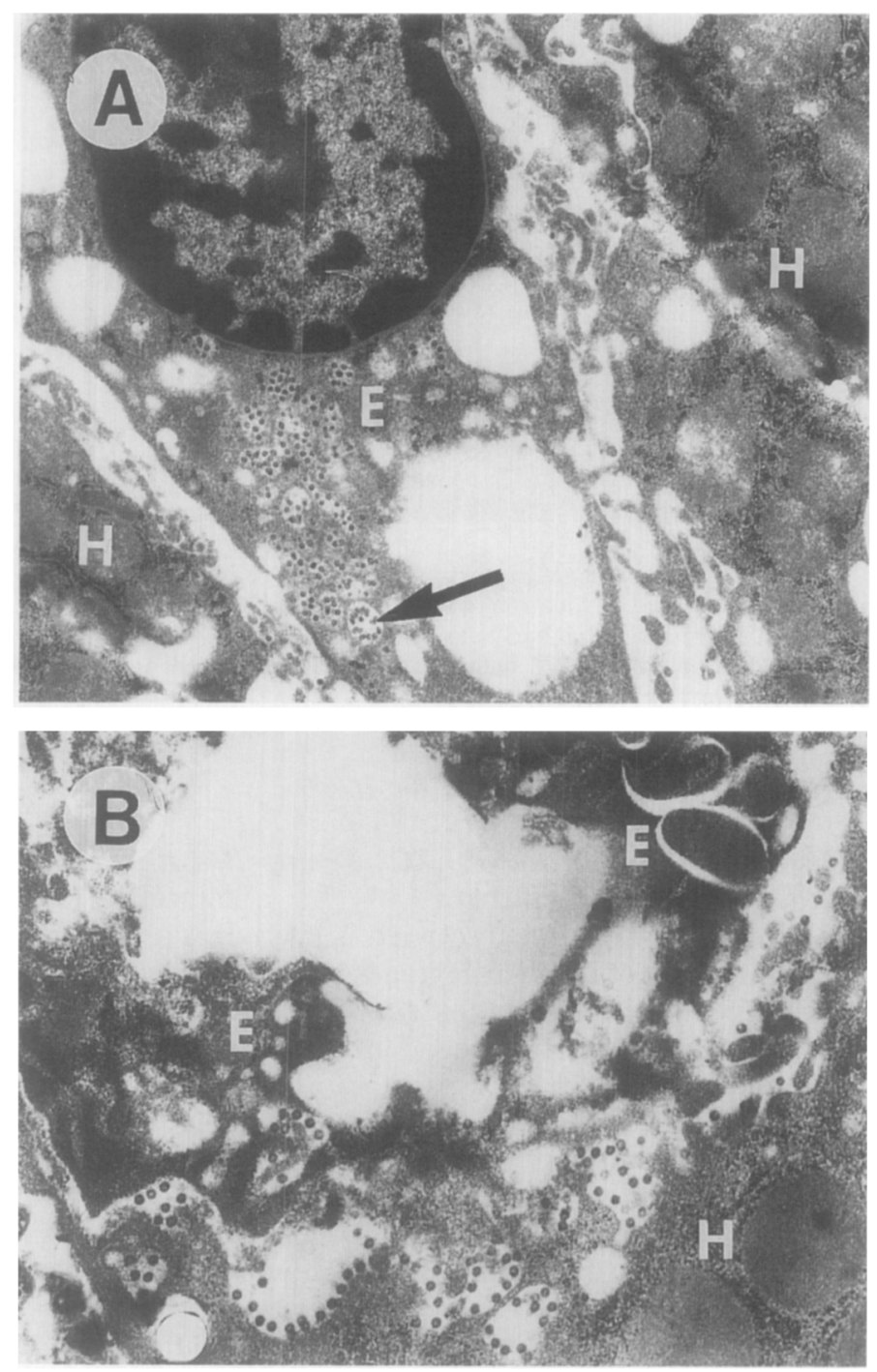

FIG. 3. TEM of EC (E) from the liver of a BALB/c mouse infected for 48 hours with MHV3. Numerous viral particles (arrow) are lying inside cytoplasmic vacuoles (A). (Original magnification $\times 12,300$.) The MHV3 particles are released inside the space of Disse from which they are taken up by the hepatocytes $(\mathrm{H})(\mathrm{B})$. (Original magnification $\times 17,400$.) 

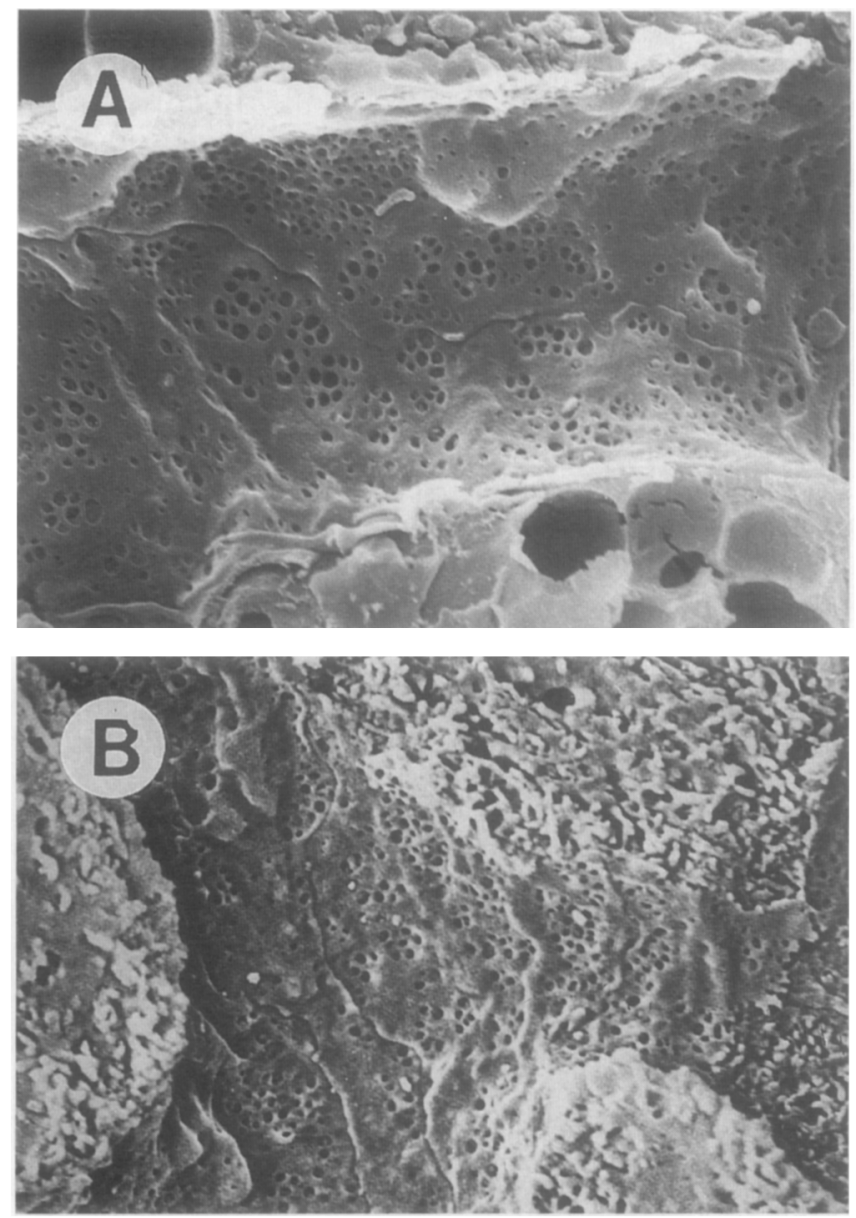

FIG. 4. Effect of MHV3 infection on the fenestration pattern in mice in which viral replication is restricted. Sinusoids from the liver of a BALB/c mouse that had been immunized with a temperaturesensitive mutant of MHV3 before being infected for 48 hours with the wild strain (A) (original magnification $\times 9,000$ ), and from a liver of a genetically resistant $\mathrm{A} / \mathrm{J}$ mouse after the same time of infection (B). (Original magnification $\times 6,000$.)

Infection of Cultured EC From BALB/c Mice. Twenty-four-hour cultures of EC isolated from $\mathrm{BALB} / \mathrm{c}$ mice were infected with MHV3 at a multiplicity of infection of 0.01 and fixed 24 hours later. As may be seen in Fig. 5A, the fenestrae in uninfected cells are well preserved and arranged in sieve plates. In the syncytia resulting from the infection (Fig. 5B) the fenestrae have almost completely disappeared (Fig. 5C), and numerous newly formed virus particles may be observed at the cell surface (Fig. 5C and 5D). It should also be noted that single cells whose infection with MHV3 was not obvious were also devoid of fenestrae (results not shown).

Effect of the Treatment With Cytochalasin B. In a recent study we reported that the treatment of $\mathrm{EC}$ with CB $(10 \mu \mathrm{g} / \mathrm{mL})$ induces a 3 to 4 times increase in the number of fenestrae. ${ }^{35}$ In the current work we wondered if infected EC were still responsive to that drug. Therefore, livers of mice infected with MHV3 for 48 hours were perfused with $\mathrm{CB}$ during 1 hour, but no fenestrae could be induced (Fig. 6A) as compared with livers of uninfected mice treated in the same way (Fig. 6B). The porosity of these CB-perfused livers reached less than $1 \%$ in infected mice versus about $20 \%$ in controls. The same experiment done with cultured EC led to similar conclusions. If a 2-hour treatment of control cells resulted in a striking increase in the number of fenestrae (Fig. 6C), infected EC demonstrated only a few enlarged pores (Fig. 6D).

\section{DISCUSSION}

The first target for MHV3 infection in the liver is Kupffer and endothelial cells in which the virus multiplies before being released into the space of Disse, from where it may infect the hepatocytes. ${ }^{44}$ We have already stressed the role of the sinusoidal cells in the pathogenesis of MHV3 by demonstrating that genetically resistant mice become susceptible to the virus if their sinusoidal lining is damaged. ${ }^{13}$ Levy et al found more viral antigen in "reticuloendothelial cells" of susceptible $\mathrm{BALB} / \mathrm{c}$ mice than in those of resistant $\mathrm{A} / \mathrm{J}$ mice. ${ }^{49}$

The decrease in the number of fenestrae seems to be the first visible alteration of hepatic EC infected with MHV3. This change affects the EC in the liver of infected animals as well as EC infected in vitro. The decrease in the number of fenestrae starts in the vicinity of the periportal area as early as 24 hours after infection and affects the whole sinusoid after 48 hours as demonstrated by a decrease in the porosity. Levy et al, who studied the perturbations in the microcirculation during MHV3 infection, found that microthrombi in the sinusoids, which we observed also in our study, after 24 hours of infection were most frequently localized in the periportal zone. ${ }^{49}$

The fact that MHV3 does not induce a modification in the pattern of the fenestration in immunized $\mathrm{BALB} / \mathrm{c}$ mice or in genetically resistant $\mathrm{A} / \mathrm{J}$ mice demonstrates that viral multiplication is necessary for this phenomenon to occur. Moreover, the defenestration is due to the direct action of the virus and not to a mediator because it may be produced in cultured infected cells. In cells infected in vitro with MHV3, the fenestrae disappear not only in multinucleated cells but also in single cells, and there is direct relationship between the amount of viral particles or viral antigen and the intensity of defenestration. This argues for an early step of the viral cycle to be involved. Two factors may be responsible for the change in the fenestration pattern: (1) a fusion process of the cellular membrane, because MHV3 is a fusion-inducing virus; (2) an alteration of the cytoskeleton. High amounts of MHV3 may lead to the fusion of cells within 45 minutes, when glycoprotein $\mathrm{E} 2$, the fusion protein, is cleaved in two $90 \mathrm{~K}$ fragments. ${ }^{50,51}$ One may thus speculate that disappearance of fenestrae by membrane fusion may occur as early as MHV3 released from lyzed $\mathrm{KC}$ enters in contact with the membrane of the EC. Conversely, fusion of cellular membrane occurs in the course of the infection: newly synthesized virus-specific proteins that mediate the appearance of the typical syncytia are 

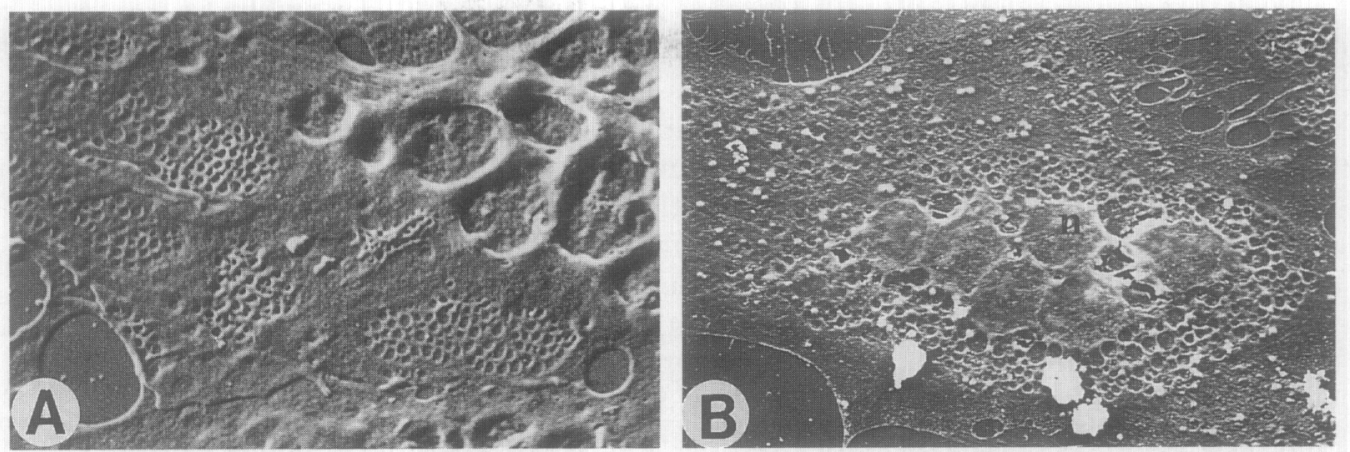

Fig. 5. Effect of MHV3 infection on cultured liver EC from $\mathrm{BALB} / \mathrm{c}$ mice. Noninfected controls display typical fenestrae arranged in sieve plates (A). (Original magnification $\times 7,500$.) Appearance of a syncytium with 6 nuclei (n) 24 hours after infection (B). (Original magnification $\times 1,400$.) At higher magnifications the absence of pores becomes evident and viral particles (arrows) are distinguished at the cell membrane $(\mathrm{C}, \mathrm{D})$. (Original magnification $\times 10,000$, $\times 40,000$.)
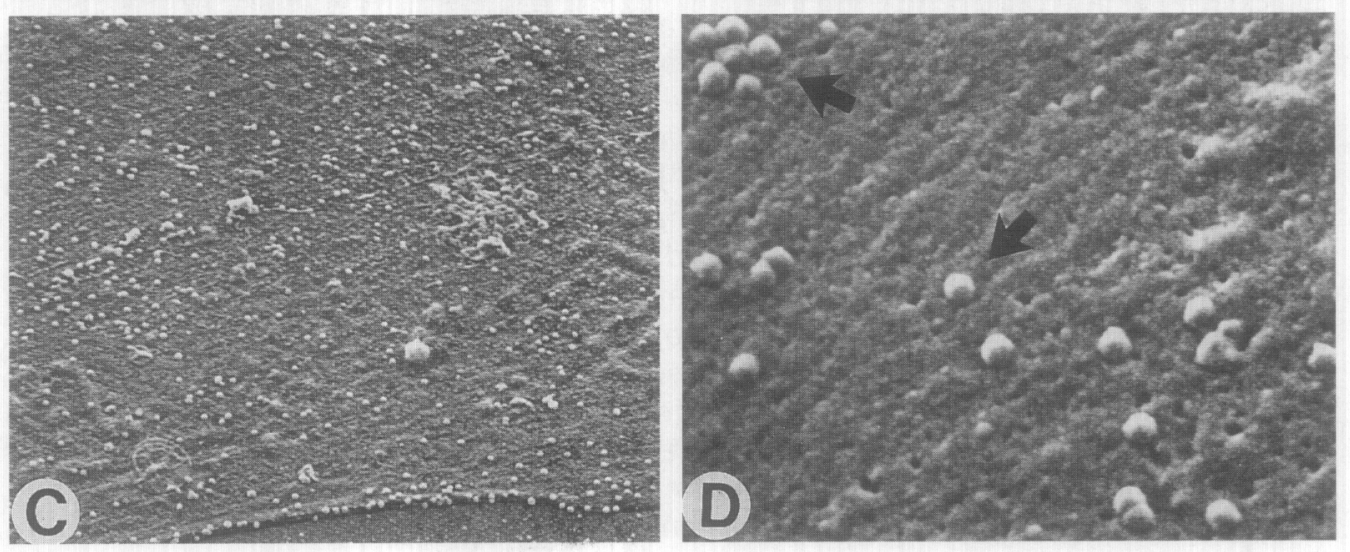

associated with the plasma membrane ${ }^{52}$ The absence of small pores in the cryofracture samples of infected cells gives evidence that a fusion of the plasma membrane occurred. However, experiments in which fusion is inhibited either by monoclonal antibodies directed against glycoprotein E2 or by protein inhibitors preventing its cleavage would be interesting and help dem- onstrate the involvement of fusion. The second factor that may be responsible for the defenestration, the alteration of the cytoskeleton, fits with fusion processes, because microfilaments are involved in the formation of fenestrae and in the modulation of their number. ${ }^{35}$ The fact that CB fails to induce fenestrae in infected cells strongly suggests that cytoskeleton function is im-
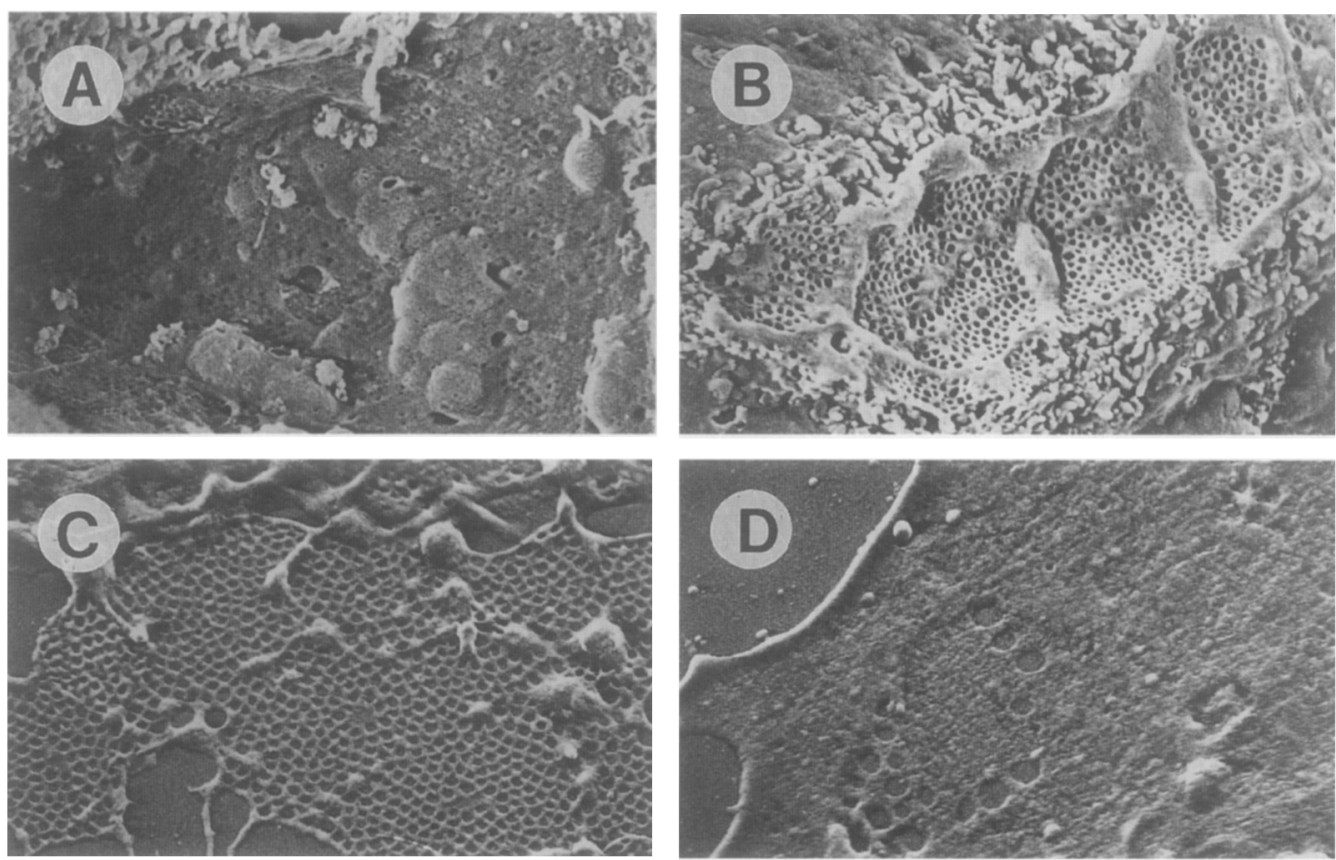

FIG. 6. Effect of cytochalasin $B(C B)$ on the fenestration pattern of noninfected and MHV3infected $\mathrm{EC}$ in vivo $(\mathrm{A}, \mathrm{B})$ and in vitro $(\mathrm{C}, \mathrm{D})$. Rare structures recalling fenestrae are observed in $\mathrm{BALB} / \mathrm{c}$ mice infected for 48 hours that were perfused for 1 hour with $\mathrm{CB}$ before fixation (A) (original magnification $\times 7,500$ ), whereas in controls numerous fenestrae are almost uniformly scattered all over the cellular surface (B). (Original magnification $\times 7,500$.) In cultured $\mathbf{E C}$ treated with CB for 2 hours, the cytoplasm is highly fenestrated (C) (original magnification $\times 7,000$.) in contrast to 24 hour-infected cells in which only a few enlarged pores could be induced (D). (Original magnification $\times 16,000$.) 
paired. Interaction of viruses with the cytoskeleton leads to very different effects on the cells. ${ }^{36-41}$ Whereas cytomegalovirus produces the disruption of microfilament ${ }^{39}$ and measles virus leads to a diminution in the amount of actin ${ }^{36}$ herpesvirus induces an increase in the actin content of the cell. ${ }^{41}$ The interaction of MHV3 with the cytoskeleton is only poorly documented. Mallucci and Edwards ${ }^{53}$ have shown that there is a relationship between cell fusion and the actin myosin system. An alteration of the cytoskeleton may already occur in MHV3 infection during the first stages when the viral particles penetrate into the cells by fusion, which may lead to changes in the permeability of the membrane, allowing small ions to destabilize the cytoskeleton.

We are studying the interactions between primary cultures of human liver sinusoidal cells with human immunodeficiency virus HIV $-1 .{ }^{54}$ This retrovirus known to induce also cellular fusions leads to no obvious modifications of the fenestration pattern in the liver of acquired immunodeficiency syndrome patients. Moreover, in vitro, fenestrae are still present in virusproducing human liver EC. ${ }^{54}$ We observed the same phenomenon in cat liver endothelial cells infected with FIV, the feline immunodeficiency virus (manuscript in preparation). It must be stressed that in the EC infected with these two retroviruses we could not detect any alterations of the microfilaments (Unpublished results).

A decrease in the number of fenestrae has been reported in diverse pathological situations like tumor invasion of the liver ${ }^{19,23,34}$ and ethanol absorption. ${ }^{17,20,25,27}$ A loss of sieve plates was also observed in chronic active hepatitis ${ }^{55}$ but, because the liver biopsy specimens were fixed by immersion, caution must be exerted to interpret these results. One may wonder what the consequences of the defenestration in vivo may be. It has been postulated that the decreased porosity of the liver sieve hinders the passage of cholesterol-rich chylomicron remnants from the blood to the hepatocytes and induces perturbation of the lipoprotein metabolism, thus favoring accumulation of fat in the hepatocytes, which could be a factor in atherogenesis. ${ }^{8}$ The steatosis characterized by an increased amount of neutral lipids described in the livers of MHV3-infected mice by others in our laboratory ${ }^{56}$ has also been observed in the current study, but the relationship between the decrease in the porosity and steatosis could not be established until now. Moreover, the infection of mice with a thermosensitive mutant of MHV3, which does not change the porosity of the EC, nevertheless produces an acute steatosis. $^{57}$

\section{REFERENCES}

1. Naito M, Wisse E. Filtrating effect of endothelial fenestrations on chylomicron transport in the neonatal rat liver. Cell Tissue Res 1978; 190:371-382.

2. Wisse E, Van Dierendonck JH, De Zanger RB, Fraser R, McCuskey RS. On the role of the liver endothelial filter in the transport of particulate fat (chylomicrons and their remnants) to parenchymal cells and the influence of certain hormones on the endothelial fenestrae. In: Popper H, Bianchi L, Gudat F, Reutter W, eds. Communications of liver cells. Lancaster: MTP Press Ltd., 1980:195-200.

3. De Zanger RB, Wisse E. The filtration effect of rat liver fenestrated sinusoidal endothelium on the passage of (remnant) chylomicrons to the space of Disse. In: Knook DL, Wisse E, eds. Sinusoidal liver cells. Amsterdam: Elsevier/North-Holland Biomedical Press, 1982:69-76.

4. Wisse E, De Zanger RB, Jacobs R, McCuskey RS. Scanning electron microscope observations on the structure of portal veins, sinusoids and central veins in rat liver. Scanning Electron Microse 1983;3:1441-1452.

5. Oda M, Tsukada N, Watanabe N, Komatsu H, Yonei Y, Tsuchida M. Functional implications of the sinusoidal endothelial fenestrae in the regulation of the hepatic microcirculation [Abstract]. HEPATOLOGY 1984;4:754.

6. Wisse E, De Zanger RB, Charels K, Van der Smissen $P$, McCuskey RS. The liver sieve: considerations concerning the structure and function of endothelial fenestrae, the sinusoidal wall and the space of Disse. HEPATOLOGY 1985; $5: 683-692$.

7. Fraser R, Day WA, Fernando NS. Atherosclerosis and liver sieve. In: Kirn A, Knook DL, Wisse E, eds. Cells of the hepatic sinusoid. Vol. 1. Rijswijk: The Kupffer Cell Foundation, 1986:317-322.

8. Fraser R, Day WA, Fernando NS. Review: the liver sinusoidal cells: their role in disorders of the liver, lipoprotein metabolism and atherogenesis. Pathology 1986; 18:5-11.

9. McCuskey RS, Wisse E. Heterogeneity of the hepatic microvasculature. Anat Rec 1986;214:78A-79A.

10. Arias IM. The biology of hepatic endothelial cell fenestrae. In: Popper H, Schaffner F, eds. Progress in liver disease. Vol. IX. Philadelphia: Saunders, 1990:11-26.

11. Gatmaitan Z, Arias IM. Hepatic endothelial cell fenestrae. In: Knook DL, Wisse E, eds. Cells of the hepatic sinusoid. Vol. 4. Leiden: The Kupffer Cell Foundation, 1993:3-7.

12. Steffan AM, Kirn A. Multiplication of vaccinia virus in the livers of mice after frog virus 3 -induced damage to sinusoidal cells. J Reticuloendothel Soc 1979;26:531-538.

13. Pereira CA, Steffan AM, Kirn A. Kupffer and endothelial liver cell damage renders $\mathrm{A} / \mathrm{J}$ mice susceptible to mouse hepatitis virus type 3 . Virus Res 1984; 1:557-563.

14. Fraser R, Heslop VR, Murray FEM, Day WA. Ultrastructural studies of the portal transport of fat in chickens. Br J Exp Pathol 1986;67:783-791.

15. Frenzel H, Kremer B, Hücker $H$. The liver sinusoids under various pathological conditions: a TEM and SEM study of rat liver after respiratory hypoxia, telecobalt-irradiation and endotoxin application. In: Wisse E, Knook DL, eds. Kupffer cells and other liver sinusoidal cells. Amsterdam: Elsevier/North-Holland Biomedical Press, 1977:213-222.

16. Van Dierendonck JH, Van der Meulen J, De Zanger RB, Wisse E. The influence of hormones on the diameter of the fenestrae in the endothelial lining of rat liver sinusoids: a SEM study [Abstract]. Ultramicroscopy 1979;4:149.

17. Fraser R, Bowler LM, Day WA. Damage of rat liver sinusoidal endothelium by ethanol. Pathology 1980;12:371-376.

18. Fraser R, Bowler LM, Day WA, Dobbs B, Johnson HD, Lee D. High perfusion pressure damages the sieving ability of sinusoidal endothelium in rat livers. Br J Exp Pathol 1980;61:222-228.

19. Madarame T, Sasou S, Masuda T, Monma N, Satodate R, Sato S. Importance of the sinusoidal fenestration for blood monocytes to settle on the sinusoidal surface [Abstract]. J Leukoc Biol $1984 ; 36: 206$.

20. Mak KM, Lieber CS. Alterations in endothelial fenestrations in liver sinusoids of baboons fed alcohol: a scanning electron microscopic study. HEPATOLOGY 1984;4:386-391.

21. Arias IM, Gatmaitan Z, Mikkelson R, Penman S, Fay E. On the dynamic nature of hepatic endothelial cell fenestrae [Abstract]. HePATOLOGY 1986;6:1222.

22. Oda M, Tsukada N, Komatsu H, Yonei Y, Honda K, Tsuchiya $M$. Mechanism of contraction and dilatation of sinusoidal endothelial fenestrae in the liver [Abstract]. HEPATOLOGY 1986;6:771.

23. Madarame T, Masuda T, Suzuki A, Satodate R, Suzuki K, Sato $\mathrm{S}$. Ultrastructural features of the vascular channel of human 
and experimentally induced hepatocellular carcinoma. In: Kirn A, Knook DL, Wisse E, eds. Cells of the hepatic sinusoid. Vol. 1. Rijswijk: The Kupffer Cell Foundation, 1986:399-404.

24. Barbera-Guillem E, Vidal-Vanaclocha F. Concomitant variation of the fenestration pattern in endothelial cells of liver sinusoids colonized by malignant tumor cells. In: Kirn A, Knook DL, Wisse E, eds. Cells of the hepatic sinusoid. Vol. 1. Rijswijk: The Kupffer Cell Foundation, 1986:495-496.

25. Charels K, De Zanger RB, Van Bossuyt H, Van der Smissen P, Wisse E. Influence of acute alcohol administration on endothelial fenestrae of rat livers: an in vivo and in vitro scanning electron microscopic study. In: Kirn A, Knook DL, Wisse E, eds. Cells of the hepatic sinusoid. Vol. 1. Rijswijk: The Kupffer Cell Foundation, 1986:497-502.

26. Tsukada N, Oda M, Yonei Y, Honda K, Akaiwa Y, Kiryu Y, Tsuchiya M. Alterations of the hepatic sinusoidal endothelial fenestrae in response to vasoactive substances in the rat-in vivo and in vitro studies. In: Kirn A, Knook DL, Wisse E, eds Cells of the hepatic sinusoid. Vol. 1. Rijswijk: The Kupfer Cell Foundation, 1986:515-516.

27. Horn T, Christoffersen P, Henriksen JH. Alcoholic liver injury: defenestration in noncirrhotic livers: a scanning electron microscopic study. HEPATOLOGY 1987;7:77-82.

28. Clark SA, Bramwell Cook H, Oxner RBG, Angus HB, George PM, Fraser R. Defenestration of hepatic sinusoids as a cause of hyperlipoproteinaemia in alcoholics. Lancet 1988;2:1225-1227.

29. McGuire RF, Bissell DM, Boyles J, Roll FJ. Role of extracellular matrix in regulating fenestrations of sinusoidal endothelial cells isolated from normal rat liver. HEPATOLOGY 1992;15:989-997.

30. Mori T, Okanoue T, Sawa Y, Hori N, Ohta M, Kagawa K. Defenestration of the sinusoidal endothelial cell in a rat model of cirrhosis. HEPATOLOGY 1993;17:891-897.

31. Oda M, Kazemoto S, Kaneko H, Yokomori H, Ishii K, Tsukada N, Watanabe $\mathrm{N}$, et al. Involvement of $\mathrm{Ca}++$-calmodulin-actomyosin system in contractility of hepatic sinusoidal endothelial fenestrae. In: Knook DL, Wisse E, eds. Cells of the hepatic sinusoid. Vol. 4. Leiden: The Kupffer Cell Foundation, 1993:174-178.

32. Tamba-Lebbie B, Rogers GWT, Dobbs BR, Fraser R. Defenestration of the hepatic sinusoidal endothelium in the dimethylnitrosamine fed rat: is this process reversible? In: Knook DL, Wisse E, eds. Cells of the hepatic sinusoid. Vol. 4. Leiden: The Kupffer Cell Foundation, 1993:179-181.

33. Madarame T, Nagaoka T, Inomata M, Kaneta H, Yoshida T, Suzuki K, Sato S, et al. Relationship between endothelial structure and capillarization in fatty liver. In: Knook DL, Wisse E, eds. Cells of the hepatic sinusoid. Vol. 4. Leiden: The Kupffer Cell Foundation, 1993:191-192.

34. Nagura T, Shiratori Y, Fukushi Y, Kiriyama H, Hai K, Takada $\mathrm{H}$, Matsumoto K, et al. Morphological changes of hepatic sinusoidal cells during metastasis of colon carcinoma. In: Knook DL, Wisse E, eds. Cells of the hepatic sinusoid. Vol. 4. Leiden: The Kupffer Cell Foundation, 1993:530-533.

35. Steffan AM, Gendrault JL, Kirn A. Increase in the number of fenestrae in mouse endothelial liver cells by altering the cytoskeleton with cytochalasin B. HEPATOLOGY 1987;7:1230-1238.

36. Bedows $\mathrm{E}$, Rao KMK, Welsh MJ. Fate of microfilaments in vero cells infected with measles virus and herpes simplex virus type 1. Mol Cell Biol 1983;3:712-719.

37. Murti KG, Goorha R. Interaction of frog virus-3 with the cytoskeleton. I. Altered organization of microtubules, intermediate filaments, and microfilaments. J Cell Biol 1983;96:1248-1257.

38. Chen M, Goorha R, Murti KG. Interaction of frog virus 3 with the cytomatrix. IV. Phosphorylation of vimentin precedes the reorganization of intermediate filaments around the virus assembly sites. J Gen Virol 1986;67:915-922.

39. Jones NL, Lewis JC, Kilpatrick BA. Cytoskeletal disruption dur- ing human cytomegalovirus infection of human lung fibroblasts. Eur J Cell Biol 1986;41:304-312.

40. Dienes HP, Hiller G, Müller S, Falke D. Microtubules and intermediate filaments of herpes simplex virus infected cells. Arch Virol 1987;94:15-28.

41. Nørregard Nielsen L, Forchhammer J, Dabelsteen E, Jepsen A, Stubbe Teglbjaerg C, Norrild B. Herpes simplex virus-induced changes of the keratin type intermediate filament in rat epithelial cells. J Gen Virol 1987;68:737-748.

42. Steffan AM, Kirn A. Infection de cellules endothéliales de foie humain et murin en culture avec le virus vaccinal et le "Frog Virus 3" (FV3). Ann Virol (Inst. Pasteur) 1982;133E:439-453.

43. Pereira CA, Steffan AM, Kirn A. Interaction between mouse hepatitis viruses and primary cultures of Kupffer and endothelial liver cells from resistant and susceptible inbred mouse strains. J Gen Virol 1984;65:1617-1620.

44. Steffan AM, Pereira CA, Kirn A. Role of sinusoidal cells in the course of the hepatitis induced by mouse hepatitis virus type 3 (MHV3) in mice. In: Kirn A, Knook DL, Wisse E, eds. Cells of the hepatic sinusoid. Vol. 1. Rijswijk: The Kupffer Cell Foundation, 1986:377-378.

45. Martin JP, Koehren F, Rannou JJ, Kirn A. Temperature-sensitive mutants of mouse hepatitis virus type $3(\mathrm{MHV}-3)$ : isolation, biochemical and genetic characterization. Arch Virol 1988;100: $147-160$.

46. Steffan AM, Lecerf F, Keller F, Cinqualbre J, Kirn A. Isolement et culture de cellules endothéliales de foies humain et murin. CR Acad Sci Paris (Série III) 1981;292:809-815.

47. Steffan AM, Gendrault JL, McCuskey RS, McCuskey PA, Kirn A. Phagocytosis, an unrecognized property of murine endothelial liver cells. HePATOLOGY 1986;6:830-836.

48. Nation JL. A new method using hexamethyldisilazane for preparation of soft insect tissues for scanning electron microscopy. Stain Technol 1983;58:347-351

49. Levy GA, MacPhee PJ, Fung LS, Fisher MM, Rappaport AM. The effect of mouse hepatitis virus infection on the microcirculation of the liver. Hepatology 1983;3:964-973.

50. Sturman LS, Ricard CS, Holmes KV. Proteolytic cleavage of the E2 glycoprotein of murine coronavirus: activation of cell-fusing activity of virions by trypsin and separation of two different $90 \mathrm{~K}$ cleavage fragments. J Virol 1985; 56:904-911.

51. Frana MF, Behnke JN, Sturman LS, Holmes KV. Proteolytic cleavage of the $\mathrm{E} 2$ glycoprotein of murine coronavirus: host-dependent differences in proteolytic cleavage and cell fusion. $J$ Virol 1985;56:912-920.

52. Robb JA, Bond CW. Pathogenic murine coronaviruses. I. Characterization of biological behavior in vitro and virus-specific intracellular RNA of strongly neurotropic JHMV and weakly neurotropic A59V viruses. Virology 1979;94:352-370.

53. Mallucci L, Edwards B. Influence of the cytoskeleton on the expression of a mouse hepatitis virus (MHV-3) in peritoneal macrophages: acute and persistent infection. J Gen Virol 1982;63:217221

54. Steffan AM, Lafon ME, Gendrault $\int L$, Schweitzer C, Royer C, Jaeck D, Arnaud JP, et al. Primary cultures of endothelial cells from the human liver sinusoid are permissive for human immunodeficiency virus type 1. Proc Natl Acad Sci U S A 1992; $89: 1582-1586$.

55. Bardadin KA, Desmet VJ. Ultrastructural observations on sinusoidal endothelial cells in chronic active hepatitis. Histopathology 1985;9:171-181.

56. Bingen A, Martin JP, Klein F, Pessah M. Modification of the amount of cholesterol in hepatic steatosis induced in susceptible and resistant mice infected with MHV3: a biochemical and ultrastructural study. HEPATOLOGY 1992; $15: 1137-1146$.

57. Martin JP, Bingen A, Koehren F, Gut JP, Kirn A. Altered pathogenicity in the liver induced by a mouse hepatitis virus type 3 thermosensitive mutant. J Hepatol 1991;13:61-70. 